Brit. J. industr. Med., 1957, 14, 164.

\title{
A ROUTINE METHOD FOR THE PREPARATION OF THE CELLS OF URINE
}

\author{
BY \\ PHILIP ROFE \\ From the Industrial Hygiene Research Laboratories, Imperial Chemical Industries, Limited, The Frythe, Welwyn, Herts.
}

(RECEIVED FOR PUBLICATION FEBRUARY 26, 1957)

The value of urinary cytology in the screening of a large industrial population at risk to bladder carcinogens has been amply demonstrated by Crabbe, Cresdee, Scott, and Williams (1956). The standard method of Papanicolaou and Marshall (1945) by which the exfoliated cells are prepared for examination consists simply of smearing the deposit of fixed centrifuged urine on to albuminized slides and staining. Unfortunately, this technique limits the diagnostic value of exfoliative cytology because only a small and possibly unrepresentative proportion of the cells in a given urine sample are prepared for examination, and these are so widely dispersed in the smear that the labour of finding them further reduces the numbers actually seen. Determinations of the rates of exfoliation of transitional and squamous epithelial cells from the urinary tract in 12 normal males (Rofe, 1955) showed characteristic rates for individuals, the lowest of which was 6.2 thousands/hour and the highest 148 thousands/ hour. An hour's urine sample, say $60 \mathrm{ml}$., might thus be expected to contain at least 6,000 cells, yet smears of urine sediment, which usually cover the whole area of a slide, are sometimes found to contain no cells or too few cells on which to report (Chute and Williams, 1948; Vincent Memorial Hospital, 1950; Deden, 1954). Presti and Weyrauch (1955) found as many as $22 \%$ of samples $(100 \mathrm{ml}$.) produced smears containing less than six cells, but were prepared to interpret smears containing more than this number of cells: this might well account for the unsatisfactory results referred to by them. Schmidlapp and Marshall (1948) refer to instances of finding malignant cells only after several specimens had been examined, and Crabbe (1956) feels that a single smear could quite possibly show no malignant cells although these are present in the sample as a whole: in this way a false negative report could arise.

It is evident that the reliability of cytological diagnosis is increased if ample numbers of cells are obtained from every urine sample. If in addition the cells are concentrated within relatively few fields of the microscope, the labour of surveying the whole area of one or more smeared slides is avoided. The present paper describes a procedure by which virtually all the cells in a sample of urine may be mounted within a small area. The method is suitable for routine use and has been found satisfactory over a trial period of several months. Most of the samples received for screening are, of course, normal: Fig. 1 demonstrates the kind of preparation obtained from normal male urine. It will be appreciated that if, for example, the only abnormal cells in a urine sample were one or two small clumps, their detection would be relatively easy compared with the likelihood of observing them in one of several possible smears occupying a total area perhaps fifty times greater.

The working time required per sample is wholly comparable to the smear technique when account is taken of the elimination of the tedious scanning of each smear. A technician, working alone and using a six-place centrifuge, mounts and stains the whole cell content of 12 urine samples in about one and a half hours; examination takes only a few minutes. Thus the whole procedure, including examination, takes no longer than the smear technique, and the much larger number of cells examined per patient seems likely to improve diagnostic accuracy, particularly in cases where only a very few suspicious or malignant cells are being exfoliated. The time taken to carry out the test for microscopic haematuria (Oppenheimer, 1920; Crabbe, et al., 1956) could be saved, as erythrocytes also appear in the preparation.

\section{Technique}

The principle used has been stated earlier (Rofe, 1955). It consists of the fixation of cells of urinary sediment by alcohol followed by the solution of mucus by addition of water. The centrifuged mucus-free deposit is allowed 


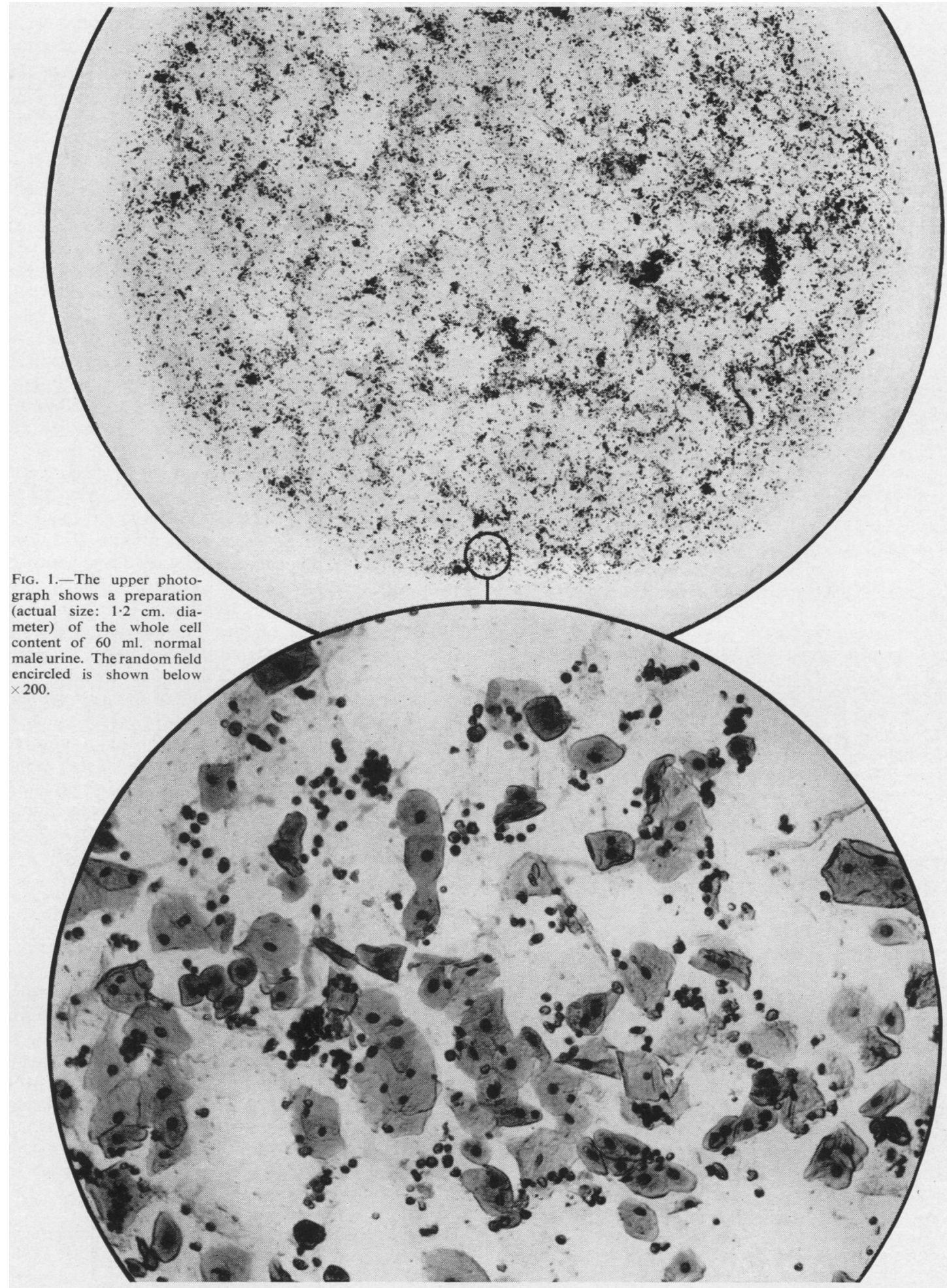


to dry on a slide in the presence of added albumen and glycerine.

The procedure is as follows:-

Samples which are not perfectly clear receive a few drops of $\mathrm{N} \mathrm{HCl}$ until $p \mathrm{H} 5 \cdot 0-5 \cdot 5$ is shown by indicator paper. The urines are spun for 10 minutes at $1,750 \mathrm{~g}$.* and the supernatant liquid poured away.

Absolute alcohol $(10 \mathrm{ml}$.) is added in the form of a jet from a syringe so as to mix the sediment thoroughly.

After five to 10 minutes, $8 \%$ glycerine solution at $p \mathrm{H} 7$ is run in from a reservoir slowly at first with shaking, then more quickly to fill the centrifuge tube to a mark at $60 \mathrm{ml}$. This is followed by $0.15 \mathrm{ml}$. of $1 \%$ egg albumen $\dagger$ solution and the tube inverted to mix.

The cells are now concentrated for 10 minutes at $1,750 \mathrm{~g}$., the supernatant liquid is poured off and spinning continued for a further five minutes. During this period more liquid accumulates by drainage from the walls and this is removed by a Pasteur pipette until a depth equal to that of the cell deposit is left, i.e., just enough to re-suspend the cells.

The whole suspension (about $0.02 \mathrm{ml}$.) is then taken up in the pipette stem and gently expelled on to a greasefree slide as a single drop. The area of the drop is enlarged by means of a needle until the curved meniscus becomes flat (diameter $0.5-1 \cdot 5 \mathrm{~cm}$.). The slide is then left to dry in a warm, dust-free situation for about half-an-hour, or longer if desired, since the glycerine protects the cells from the distortion usually associated with drying.

The staining procedure is as follows: alcohol/ether, equal parts, one minute; absolute alcohol, five minutes; $70 \%$ alcohol; $50 \%$ alcohol; Harris haematoxylin, three minutes; $50 \%$ alcohol; $0.88 \mathrm{NH}_{4} \mathrm{OH}, 0.5 \%$ in $70 \%$ alcohol, 30 seconds; $70 \%$ alcohol; $0.5 \%$ orange $\mathrm{G}$ in 95\% alcohol, one-and-a-half minutes; absolute alcohol, 10 seconds; Papanicolaou polychrome stain, three minutes; absolute alcohol, 10 seconds; xylol; neutral mountant.

\section{General Notes}

The dimensions of the centrifuge tubes which have been used are: outside diameter $1 \frac{3}{16}$ in.; wallthickness $\frac{3}{32}$ in.; length $6 \frac{1}{4}$ in. of which the final $1 \frac{3}{4}$ in. tapers evenly, i.e., with the same slope throughout, to a point. Internally the tip should be fairly sharp so that the final cell deposit, which is very small, forms an inverted cone enabling the relative depths of deposit and of liquid to be judged. To prevent the pointed centrifuge tube piercing the centrifuge bucket the pressure is distributed by a nylon + disc $\frac{1}{2}$ in. thick surmounting a $\frac{1}{8}$ in. thick rubber disc. A suitable Pasteur pipette should have a terminal drawn-out portion $\frac{3}{4}$ in. long with outside diameter $\frac{1}{32} \mathrm{in}$. and inside diameter $\frac{1}{64} \mathrm{in}$.

* 2,500 r.p.m. for the centrifuge used.

† Egg albumen flake (British Drug Houses Ltd.). Dissolve at $p \mathbf{H}$ 8 to 9 and filter.

‡66 nylon, I.C.I. Plastics Division.

Much time can be saved by eliminating the usual balancing procedure before spinning. If suitably robust centrifuge tubes are employed, the use of water in the centrifuge buckets is unnecessary. Thus, a suitable number of units each comprising centrifuge tube, bucket, nylon disc, and rubber disc, may be adjusted permanently to a uniform weightmetal foil placed at the bottom of each bucket has been found convenient-and thereafter it is only necessary to fill each tube to the $60 \mathrm{ml}$. mark to obtain adequate balance. If a sample is less than $60 \mathrm{ml}$., saline may be used to make up the volume. Two other time-saving measures are well worth while if the method is to be used routinely. The syringe used for adding alcohol as a jet can be made semi-automatic by the addition of a reservoir, inlet and outlet valves, and a spring to withdraw the plunger. The washing and drying of the Pasteur pipettes in bulk also saves time and a device for this purpose is to be published (Rofe, 1957, in press).

Care should be taken at all stages to prevent the introduction of dirt, which becomes concentrated along with the cells. The alcohol used for fixation, and also the distilled water, may require filtration. Bottles supplied for the collection of urine samples from workmen should have as narrow a neck as is thought practicable; this minimizes the amount of dust falling from the clothes into the sample during micturition. Textile fibres may be readily removed if the second spin is stopped after 15 minutes.

The experimental induction of cancer of the bladder in the dog by various chemicals has led to the study of the urinary cytology as a control measure. A large number of samples of dog urine have been processed according to the above method, and the only modification which has been found necessary is an initial adjustment to $p \mathrm{H} 4$ to dissolve crystals.

\section{Summary}

A method is described by which the whole cell content of a sample of urine may be mounted within a small area and stained.

The method is suitable for use as a routine, particularly in screening for bladder cancer by exfoliative cytodiagnosis.

The advantage over the standard technique of smearing the urine sediment lies chiefly in the assurance of an adequate number of cells being obtained from every urine sample: this is particularly valuable where only a very few tumour cells are present, and in such cases may well lead to earlier diagnosis.

I wish to acknowledge the support and encouragement of Dr. M. W. Goldblatt, C.B.E., and of Dr. J. G. S. 
Crabbe, who also kindly supplied a number of literature references.

I am indebted to Mr. K. D. Cooper for the preparation of the photographs. For invaluable technical assistance I am grateful to Miss J. B. Martin.

\section{REFERENCES}

Chute, R., and Williams, D. W. (1948). J. Urol. (Baltimore), 59, 604. Crabbe, J. G. S. (1956). Personal communication.
Cresdee, W. C., Scott, T. S., and Williams, M. H. C. (1956). British Journal of Industrial Medicine, 13, 270

Deden, C. (1954). Acta radiol. (Stockh.). Suppl. 115.

Oppenheimer, R. (1920). Zbl. GewHyg., 8, 105.

Papanicolaou, G. N. and Marshall, V. F. (1945). Science, 101, 519. Presti, J. C., and Weyrauch, H. M. (1955). J. Urol. (Baltimore), Presti, $73,430$.

Rofe, P. (1955). J. clin. Path., 8, 25.

(1957). Lab. Pract. In press.

Schmidlapp, C. J. II., and Marshall, V. F. (1948). J. Urol. (Baltimore), $59,599$.

Vincent Memorial Hospital (1950). The Cytologic Diagnosis of Cancer. Saunders, Philadelphia and London.

\section{THE APRIL (1957) ISSUE}

The April (1957) issue contains the following papers:-

The Health of the Worker. By P. A. B. Raffle.

The Neutralization of Silica Toxicity in vitro. By J. Marks.

Silicosis Hazards in Enamelling: A Medical, Technical, and Experimental Study. By Lars Friberg and Harry Öhman.

Some Factors Influencing the Response of Industrial Workers to Mass Radiography. By G. Z. Brett.

Radiological Surveys of Working Quarrymen and Quarrying Communities in Caernarvonshire. By T. Francis Jarman, J. Glyn Jones, J. H. Phillips, and H. E. Seingry.

An Outbreak of Weaver's Cough Associated with Tamarind Seed Powder. By Robert Murray, I. Dingwall-Fordyce, and Ronald E. Lane.

An Outbreak of Tri-ortho-cresyl Phosphate (T.O.C.P.) Poisoning in Durban. By Mervyn Susser and Zena Stein.

Internal Derangement of the Knee Joint in Miners. By J. B. Atkins.

The Responsibilities of the Medical Profession in the Use of X Rays and Other Ionizing Radiations. By United Nations Scientific Committee on the Effects of Atomic Radiation.

Miscellanea:

Occupational Mortality in Scotland. By S. L. Morrison.

Work, Conflict, and Community. By D. H. Allcorn.

A Discussion of Technique and an Analysis of Errors in Taking Industrial Histories in Coal-miners. By G. Jonathan, F. Moore, and L. Roberts.

A New Kit for Sodium Nitrite-thiosulphate Therapy in the Treatment of Acute Cyanide Poisoning. By N. Langdon Lloyd.

\section{Book Reviews.}

A number of copies are still available and may be obtained from the Publishing Manager, British Medical Association, Tavistock Square, W.C.1, price 12s. 6d. 